\title{
Parasites of the Antarctic toothfish (Dissostichus mawsoni Norman, 1937) (Perciformes, Nototheniidae) in the Pacific sector of the Antarctic
}

\author{
Ilya I. Gordeev ${ }^{1} \&$ Sergey G. Sokolov ${ }^{2}$ \\ ${ }^{1}$ Laboratory of Ecology and Bioresources of the Arctic and Antarctic, Russian Federal Research Institute of Fisheries and Oceanography, 17, \\ V. Krasnoselskaya St.,107140 Moscow, Russia \\ ${ }^{2}$ Laboratory of Fauna and Ecology of Parasites, Center of Parasitology, A.N. Severtsov Institute of Ecology and Evolution, Russian Academy of \\ Sciences, 33, Leninsky pr.,119071 Moscow, Russia
}

\author{
Keywords \\ Toothfish; parasites; Antarctic fisheries; \\ CCAMLR; infection; Southern Ocean.

\section{Correspondence} \\ llya I. Gordeev, Laboratory of Ecology and \\ Bioresources of the Arctic and Antarctic, \\ Russian Federal Research Institute of \\ Fisheries and Oceanography, 17, \\ V. Krasnoselskaya St., 107140 Moscow, \\ Russia. E-mail: gordeev_ilya@bk.ru
}

\begin{abstract}
The Antarctic toothfish (Dissostichus mawsoni Norman, 1937) is one of the main target species of commercial fisheries in the Antarctic. It is an endemic and is found along the shelf of Antarctica, as well as on the slopes of seamounts, underwater elevations and islands in the sub-Antarctic. It feeds on a variety of fish and cephalopods and can be an intermediate/paratenic host of some helminthes, whose final hosts are whales, seals, large rays and sharks. This article presents new data on toothfish infection in the Pacific sector of the Antarctic. Specimens were examined during commercial longline fishing in the Ross Sea and the Amundsen Sea in January-February 2013. Fourteen species of parasites were found using standard parasitological methods and genetic analysis.
\end{abstract}

The Antarctic toothfish (Dissostichus mawsoni Norman, 1937) is one of two species in the genus and one of the main target species of commercial fisheries in the Antarctic. Dissostichus mawsoni is endemic, with a circumpolar distribution along the shelf of Antarctica and on the slopes of seamounts, underwater elevations and islands in the sub-Antarctic (Shust \& Petrov 2009). The history of targeted research on the Antarctic toothfish and subsequent exploratory fishing began in 1969 (Calhaem \& Christoffel 1969), but its life cycle and biology are still poorly understood because its habitat is covered by sea ice from March to December (Juhov 1982; Andrijašev 1986; DeWitt in Gon \& Heemstra 1990; Shust et al. 2005; Hanchet 2006).

The study of Antarctic toothfish parasites includes a few studies carried out mainly in the Atlantic sector of the Southern Ocean. Sixteen species of helminthes were found near the Antarctic Peninsula (e.g., Rodjuk 1984; Gaevskaja et al. 1990; Zdzitowiecki 1990, 1991a; Rocka 2003, 2004; Rokicki et al. 2009). Three species of trematodes were found in the Ross Sea
(Holloway \& Bier 1968; Sokolov \& Gordeev 2013, 2015) as well as the copepod Eubrachiella antarctica Quidor, 1906 (Smith et al. 2006). Two species of Monogenea were recorded in the Pacific sector of the subAntarctic (Gaevskaja et al. 1990) and in the Antarctic (Oguz et al. 2012).

\section{Material and methods}

A total of 20 adult specimens of Dissostichus mawsoni (total length 97-159 cm; weight 11.23-55.04 kg) were caught between 21 and 27 January 2013 in the central part of the Ross Sea. Five specimens were caught on 3 February 2013 in the Amundsen Sea from the fishing vessel Yantar35 when fishing for toothfish at depths ranging from 865 to $1425 \mathrm{~m}$ using Mustad Autoline bottom longline fishing gear inside the Convention for the Conservation of Marine Living Resources area. All specimens were caught on the continental slope between $75^{\circ} 25^{\prime} \mathrm{S}, 174^{\circ} 42^{\prime} \mathrm{W}$ and $69^{\circ} 44^{\prime} \mathrm{S}, 126^{\circ} 46^{\prime} \mathrm{W}$. Straight after capture all specimens were examined macroscopically for the presence of 
ectoparasites and then dissected and studied for helminthes and other metazoan parasites using a standard method of parasitological examination (ByhovskajaPavlovskaja 1985). Prefixation treatment of trematodes, cestodes and monogeneas included cleaning and straightening with the compression method for better identification. Acanthocephala were transferred to freshwater until the proboscis everted prior to fixation. All parasites except nematodes were preserved in $70 \%$ and $96 \%$ ethanol. Nematodes were preserved in $4 \%$ formaldehyde and three days later transferred to $70 \%$ ethanol for longterm storage. Some nematodes were preserved in $96 \%$ ethanol. Digenea were stained with acetic carmin, dehydrated, contrasted (cleared) with dimethyl phthalate or diethyl phthalate, and finally mounted in Canada balsam. Cestoda were hydrated, stained with Harris's hematoxylin, differentiated in tap water, de-stained in ethanol, dehydrated, cleaned in methyl salicylate, and finally mounted in Canada balsam (Jensen et al. 2011).

Fish species were identified with reference to Gon $\delta$ Heemstra (1990). Parasites were identified with the aid of literature, including Holloway \& Bier (1968), Zdzitowiecki (1991b), Rocka \& Zdzitowiecki (1998), Zdzitowiecki (1999), Rocka (2003), Smith et al. (2006) and Bray et al. (2008). Tetraphyllidean and onchoproteocephalidean larvae were identified using DNA sequencing.

DNA extraction was carried out using the standard saline method (Aljanabi \& Martinez 1997). Amplifications were performed in a final reactions volume of $12.5 \mu \mathrm{l}$ : $1.5 \mu \mathrm{l}$ PCR buffer (Sileks, Russia); $2.5 \mathrm{~mm} \mathrm{MgCl}_{2}$; $0.6 \mathrm{~mm}$ dNTP; 2 pmol of each primer; $200 \mathrm{ng}$ DNAmatrix; and 1 unit of Taq-polymerase (Sileks, Moscow) with the following cycle protocol: a preliminary denaturation of DNA at $94^{\circ} \mathrm{C}$ for two minutes was followed by the syntheses of DNA products: melting at $94^{\circ} \mathrm{C}$ for $30 \mathrm{~s}$, annealing the primers at $55^{\circ} \mathrm{C}$ for $45 \mathrm{~s}$, and DNA syntheses at $72^{\circ} \mathrm{C}$ for two minutes. A final extension cycle of five minutes at $72^{\circ} \mathrm{C}$ followed. Amplification of lsuDNA was performed using primers 1200R (5'GCATAGTTCACCATCTTTCGG-3') (Lockyer et al. 2003) and LSU5 5'-TAGGTCGACCCGCTGAAYTTAAGCA-3') (Littlewood et al. 2000). Sequencing was carried out with BigDye version 1.1 on the automatic sequencer ABI 3100. Results processing and multiple alignment were carried out using the software package DNAStar (Lasergene Inc.).

\section{Results}

A total of 14 parasite taxa were detected (Table 1). The copepod Eubrachiella antarctica was found on and near the dorsal, pectoral and anal fins. The monogenean
Pseudobenedenia dissostichi Timofeeva, Gaevskaja \& Kovaliova, 1987 was found mainly between the pectoral fins, but sometimes on the rest of the body surface, except the head. Other species not listed in Table 1 -leeches (Hirudinea) Moorebdellina sp. and Pleurobdella sp.--were very common on Dissostichus mawsoni, but infection indices of these species are not available because of the lengthy contact between examined specimens in the fish-receiving.

Two morphological types of plerocercoid were found: small (1-2 $\mathrm{mm})$ with bilocular bothridia, and large (2-4 mm) with trilocular bothridia. Sequences of small plerocercoids with bilocular bothridia exhibited a 95\% match with Calyptrobothrium sp. (Genbank no. AF382087.1) collected by Brickle et al. (2001) from Apristurus laurussonii (Saemundsson, 1922) (formerly accepted as Apristurus atlanticus Koefoed, 1932) caught in the North Sea. Large plerocercoids with trilocular bothridia showed 99\% match with Onchobothrium antarcticum Wojciechowska, 1990 (Genbank no. KF882021.1) collected by Laskowski \& Rocka (2014) from Notothenia rossii Ricardson, 1844 which were caught around the South Shetland Islands.

\section{Discussion}

In comparison with other high-level predators from the near-continental areas of the ocean, data on the parasites of Dissostichus mawsoni are fragmentary and scarce. Only seven of the 14 species found in our study were previously recorded as parasites of D. mawsoni: Neolepidapedon trematomi Prudhoe \& Bray, 1973, Helicometra antarcticae Holloway \& Bier, 1968, Onchobothrium antarcticum, E. antarctica, Hysterothylacium sp., Echinorhynchus petrotschenkoi (Rodjuk 1984) and Corynosoma bullosum Linstow, 1892. Neolepidapedon trematomi and Corynosoma bullosum Linstow, 1892 were found by Zdzitowiecki (1987 1988, 1990, 1999) in the South Shetland Islands area and the first of the above-mentioned species by Sokolov \& Gordeev (2013), Sokolov \& Gordeev (2015) in the Ross Sea. Helicometra antarcticae was described by Holloway \& Bier (1968) from samples taken from D. mawsoni caught in McMurdo Sound (Ross Sea), and we later found specimens in the open waters of the Pacific sector and in the Ross Sea (Sokolov \& Gordeev 2013, 2015). Eubrachiella antarctica on the trunks of D. mawsoni in the Ross Sea was considered to be a marker or biological tag to aid stock discrimination (Smith et al. 2006). The plerocercoid $O$. antarcticum and the nematode Hysterothylacium sp. were recorded living on this species in Admiralty Bay and the open sea shelf near the South Shetlands Islands (Rocka 2003, 2004, respectively). Metechinorhynchus petrotschenkoi-later accepted as 
Table 1 Prevalence and intensity of infection and site of parasites in D. mawsoni from the Ross and Amundsen seas.

\begin{tabular}{|c|c|c|c|c|c|c|}
\hline \multirow[b]{2}{*}{ Parasite } & \multirow[b]{2}{*}{$\begin{array}{l}\text { Adult (a)/ } \\
\text { larva (I) }\end{array}$} & \multicolumn{2}{|c|}{ Ross Sea $(n=20)$} & \multicolumn{2}{|c|}{ Amundsen Sea $(n=5)$} & \multirow[b]{2}{*}{ Site } \\
\hline & & $\begin{array}{l}\text { Prevalence } \\
(\%)\end{array}$ & $\begin{array}{l}\text { Mean intensity } \\
\text { (range) }\end{array}$ & $\begin{array}{c}\text { Prevalence } \\
\text { (\%) }\end{array}$ & $\begin{array}{l}\text { Mean intensity } \\
\text { (range) }\end{array}$ & \\
\hline \multicolumn{7}{|l|}{ Copepoda } \\
\hline Eubrachiella antarctica & a & 60 & $12(1-86)$ & 36 & $3(1-6)$ & Body surface \\
\hline \multicolumn{7}{|l|}{ Monogenea } \\
\hline Pseudobenedenia dissostichi & a & 55 & $11(1-36)$ & 40 & $8(8)$ & Body surface \\
\hline \multicolumn{7}{|l|}{ Acanthocephala } \\
\hline Corynosoma bullosum ${ }^{a}$ & I & 5 & $10(10)$ & - & - & Intestine, pyloric caeca \\
\hline Corynosoma sp. ${ }^{a}$ & I & - & - & 20 & $1(1)$ & Intestine, pyloric caeca \\
\hline Echinorhynchus petrotschenkoi & a & 10 & $4(2-6)$ & 40 & $9(9-10)$ & Intestine \\
\hline Echinorhynchus sp. & a & 5 & $2(2)$ & 20 & $1(1)$ & Intestine \\
\hline \multicolumn{7}{|l|}{ Nematoda } \\
\hline Contracaecum sp. ${ }^{a}$ & । & 5 & $1(1)$ & - & - & Intestine \\
\hline Hysterothylacium sp. & a/l & 100 & $25(1-90)$ & 40 & $23(32-83)$ & $\begin{array}{l}\text { Intestine, pyloric } \\
\text { caeca, stomach }\end{array}$ \\
\hline \multicolumn{7}{|l|}{ Trematoda } \\
\hline Helicometra antarcticae & a & 55 & $33(1-243)$ & 20 & $7(7)$ & Intestine, pyloric caeca \\
\hline Neolepidapedon trematomi & a & 50 & $16(1-78)$ & 40 & $113(22-204)$ & Intestine, pyloric caeca \\
\hline Proctophantastes gillissi & a & - & - & 40 & $1(1-2)$ & Intestine \\
\hline \multicolumn{7}{|l|}{ Cestoda } \\
\hline Onchobothrium antarcticum & । & 15 & $39(1-108)$ & 60 & $10(2-21)$ & Intestine, pyloric caeca \\
\hline Diphyllobothriidae gen. sp. & । & 15 & $3(1-6)$ & 40 & $1(1)$ & $\begin{array}{l}\text { Body cavity, stomach } \\
\text { wall }\end{array}$ \\
\hline Calyptrobothrium sp. & I & 15 & $173(6-471)$ & 60 & $27(11-57)$ & Intestine, pyloric caeca \\
\hline
\end{tabular}

${ }^{\mathrm{a}}$ Aberrant parasite.

E. petrotschenkoi — was found in the South Shetland Islands area (Rodjuk 1984).

Contracoecum sp., Proctophantastes gillissi (Overstreet $\delta$ Pritchard, 1977) Bray \& Gibson, 1986, P. dissostichi, Diphyllobothriidae gen. sp. larvae and Calyptrobothrium sp. were recorded as parasites of D. mawsoni for the first time. It seems that toothfish is a postcyclic host of $P$. gillissi and becomes infected by feeding on Muraenolepis (Sokolov et al. 2016). Corynosoma sp. and Echinorhynchus sp. are not included in the list of parasites found for the first time because the poor condition of specimens made proper identification impossible. It should be noted that in the present study larvae of C. bullosum, Corynosoma sp. and Contracaecum sp. are most likely aberrant parasites of D. mawsoni. Since the larvae of these species occur mainly in the body cavity and musculature of fish, their localization in the intestine (Table 1) of the examined fishes is atypical.

Dissostichus mawsoni is most heavily infected by cestode larvae. Because of their distribution via planktonic copepods cestodes larvae are wide spread and are found in species of many families: Nototheniidae, Artedidraconidae, Bathydraconidae, Macrouridae, Channichthyidae, Myctophidae and Muraenolepididae (Rocka 2003). After being planktophagous during their short juvenile period, they then become predatory, feeding variously on bony fish, squid and octopus up to a depth of $2250 \mathrm{~m}$ (Petrov \& Istomin 2010). With growth, Antarctic toothfish become one of the biggest predators in the Antarctic waters (max. $>200 \mathrm{~cm}$ long) and are only usually eaten by sharks and whales. Therefore, tetraphyllidean larvae and plerocercoids, representing the recently created order Onchoproteocephalidea (Caira et al. 2014), accumulate in this dead-end host, reaching significant infection rates.

Other than the parasites listed in this study other researchers have found six species of trematodes: Helicometra rakusai Zdzitowiecki, 1997 in the Ross Sea (Sokolov \& Gordeev 2013), Lecithaster macrocotyle Szidat \& Graefe, 1967, Macvicaria pennelli Leiper \& Atkinson, 1914, Gonocerca phycidis Manter, 1925, Lepidapedon garrardi Leiper \& Atkinson, 1914, Neolebouria georgiensis Gibson, 1976 in the South Shetland Islands area (Zdzitowiecki 1987, 1988, 1991a, 1999). Moreover, Zdzitowiecki found Metacanthocephalus dalmori Zdzitowiecki, 1983, Corynosoma hamanni Linstow, 1892 and Corynosoma pseudohamanni Zdzitowiecki, 1984 on D. mawsoni in the South Shetland Islands area (1990). Anisakis sp. larvae and Pseudoterranova decipiens Krabbe, 1878 larvae were found on the same host and in the same area (Rokicki et al. 2009) as well as the monogenean Neopavlovskioides georgianus Kovaljova \& 
Gaevskaja, 1977 (Gaevskaja et al. 1990). Two more monogenean species were found on D. mawsoni in the Pacific sector of sub-Antarctica and near the Palmer Archipelago: Neopavlovskioides dissostichi Dillon \& Hargis, 1968 and Pseudobenedenia nototheniae Johnston, 1931 (Gaevskaja et al. 1990; Oguz et al. 2012, respectively).

Infection of Dissostichus eleginoides Smitt, 1898, a congener whose habitat overlaps with $D$. mawsoni throughout the Antarctic, including the Ross Sea, has been studied in much more depth (Brickle et al. 2006; Brown et al. 2012). Despite similar biology and feeding behaviour (Shust et al. 2009; Collins et al. 2010), D. mawsoni shares only 5 of 13 parasites recorded for $D$. eleginoides in the Ross Sea: $H$. antarcticae, the tetraphyllidean plerocercoid, Hysterothylacium sp., C. bullosum and E. petrotschenkoi (Brickle et al. 2005). Possible explanations for this are the different size ranges of the samples collected and possibly also that specimens of $D$. eleginoides were caught close to or inside the in-shelf depressions of the Ross Sea, where the main food sources of Dissostichus spp. are quite different to those on slopes and in deeper water.

Antarctic toothfish have been found to have low genetic diversity and temporal stability, so that even specimens collected thousands of kilometres apart are genetically similar (Mugue et al. 2014). Additionally, most tagged and recaptured fish were recorded less than $50 \mathrm{~km}$ from the place of their release and only $20 \%$ of fish moved more than $50 \mathrm{~km}$ (Dunn et al. in Petrov \& Tatarnikov 2010). Although they form the foundation of an important baseline, our data are limited, and it is therefore difficult to make assumptions about the parasitofauna of D. mawsoni around the Antarctic, their biogeography, or indeed their potential as indicators of host biology. However, in their study of the parasites of D. eleginoides caught around Antarctica, Brickle et al. (2005) discovered that specimens found near Heard Island, Macquarie Island and the Prince Edward Islands were the most similar, while those from the Ross Sea was the most dissimilar, based on Sørensen's Similarity Index.

Despite the fact that Antarctic toothfish is an endemic to the Antarctic, its parasitofauna includes both cosmopolitan as well as the local species found in its congener and other bony fishes.

\section{Acknowledgements}

The authors wish to thank Drs Andrey F. Petrov and Konstantin V. Shust for helping in the material collection, Dr Nikolay S. Mugue for assistance in the DNA analysis and Dr Andrey Yu. Utevsky for identification of leeches. The work was supported by Russian Foundation for Basic Research grant no. 14-04-31950.

\section{References}

Aljanabi S.M. \& Martinez I. 1997. Universal and rapid saltextraction of high quality genomic DNA for PCR-based techniques. Nucleic Acids Research 25, 4692-4693.

Andrijašev A.P. 1986. Obščij obzor fauny donnyh ryb Antarktiki. (Review of the bottom fish fauna of Antarctic regions.) Trudy Zoologiceskogo Instituta Akademii Nauk USSR 153, 9-45.

Bray R.A., Gibson D.I. \& Jones A. (eds.) 2008. Keys to the Trematoda. Vol. 3. Wallingford: CABI.

Brickle P., MacKenzie K. \& Pike A. 2005. Parasites of the Patagonian toothfish, Dissostichus eleginoides Smitt 1898, in different parts of the Subantarctic. Polar Biology 28, 663-671.

Brickle P., Mackenzie K. \& Pike A. 2006. Variations in the parasite fauna of the Patagonian toothfish (Dissostichus eleginoides Smitt, 1898), with length, season, and depth of habitat around the Falkland Islands. Journal of Parasitology 92, 282-291.

Brickle P., Olson P.D., Littlewood D.T.J., Bishop A. \& Arkhipkin A.I. 2001. Parasites of Loligo gahi from waters off the Falkland Islands, with a phylogenetically based identification of their cestode larvae. Canadian Journal of Zoology 79, 2289-2296.

Brown J., Brickle P. \& Scott B.E. 2012. The parasite fauna of the Patagonian toothfish Dissostichus eleginoides off the Falkland Islands. Journal of Helminthology 87, 501-509.

Byhovskaja-Pavlovskaja I.E. 1985. Parazity pyb. (Parasites of fishes.) Leningrad: Nauka.

Caira J.N., Jensen K., Waeschenbach A., Olson P.D. \& Littlewood D.T.J. 2014. Orders out of chaos-molecular phylogenetics reveals the complexity of shark and stingray tapeworm relationships. International Journal for Parasitology 44, 55-73.

Calhaem I. \& Christoffel D.A. 1969. Some observations of the feeding habits of a Weddell seal, and measurements of its prey, Dissostichus mawsoni, at McMurdo Sound, Antarctica. New Zealand Journal of Marine and Freshwater Research 3, 181-190.

Collins M.A., Brickle P., Brown J. \& Belchier M. 2010. The Patagonian toothfish: biology, ecology and fishery. Advances in Marine Biology 58, 227-300.

Gaevskaja A.V., Rodjuk G.N. \& Paruhin A.M. 1990. Osobennosti i formirovanie parazitofauny Patagonskogo klykaca Dissostichus eleginoides. (Peculiarities and formation of parasitofauna of the Patagonian toothfish Dissostichus eleginoides.) Biologija Morja 4, 23-28.

Gon O. \& Heemstra P.C. (eds.) 1990. Fishes of the Southern Ocean. Grahamstown: J.L.B. Smith Institute of Ichthyology.

Hanchet S.M. 2006. Species profile for Antarctic toothfish (Dissostichus mawsoni). Paper presented at the Working Group on Fish Stock Assessment of CCAMLR as document WG-FSA-06/26. 9-20 October, Hobart, Australia.

Holloway H.L. \& Bier J.W. 1968. Helicometra antarcticae sp. nov. from Antarctic coastal fishes. Proceedings of the Helminthological Society of Washington 35, 30-34.

Jensen K., Nikolov P. \& Caira J.N. 2011. A new genus and two new species of Anteroporidae (Cestoda: Lecanicephalidea) 
from the darkspotted numbfish, Narcine maculata (Torpediniformes: Narcinidae), off Malaysian Borneo. Folia Parasitologica 58, 95-107.

Juhov V.L. 1982. Antarkticeskij klykac. (Antarctic toothfish.) Moscow: Nauka.

Laskowski Z. \& Rocka A. 2014. Molecular identification larvae of Onchobothrium antarcticum Cestoda: Tetraphyllidea) from marbled rockcod, Notothenia rossii, in Admiralty Bay (King George Island, Antarctica). Acta Parasitlogica 59, 767-772.

Littlewood D.T.J., Curini-Galletti M. \& Herniou E.A. 2000. The interrelationships of Proseriata (Platyhelminthes: Seriata) flatworms tested with molecules and morphology. Molecular Phylogenets Evolution 16, 449-466.

Lockyer A.E., Olson P.D. \& Littlewood D.T.J. 2003. Utility of complete large and small subunit rRNA genes in resolving the phylogeny of the Platyhelminthes: implications and a review of the cercomer theory. Biological Journal of the Linnean Society 78, 155-173.

Mugue N.S., Petrov A.F., Zelenina D.A., Gordeev I.I. \& Sergeev A.A. 2014. Low genetic diversity and temporal stability in the Antarctic toothfish (Dissostichus mawsoni) from nearcontinental seas of Antarctica. CCAMLR Science 21, 1-10.

Oguz M.C., Heckmann R.A., Cheng C.H.C. \& El-Naggar A. 2012. Ecto and endoparasites of some fishes from the Antarctic region. Scientia Parasitologica 13, 119-128.

Petrov A.F. \& Istomin I.G. 2010. Pitanie i piščeviye vzaimootnošenija D. mawsoni Norman (Perciformes, Nototheniidae) v primaterikovyh morjah Indookeanskogo sectora Antarktiki i na banke BANZARE. (Feeding and food relations of $D$. mawsoni Norman [Perciformes, Nototheniidae] in the nearcontinental seas of the Indian sector of the Antarctic and at the BANZARE bank.) Voprosy Rybolovstva 11, 817-830.

Petrov A.F. \& Tatarnikov V.A. 2010. New data on migrations of Antarctic toothfish Dissostichus mawsoni in the Dumont d'Urville Sea in the 2008/2009 season. Journal of Ichthyology 50, 140-141.

Rocka A. 2003. Cestodes of the Antarctic fishes. Polish Polar Research 24, 261-276.

Rocka A. 2004. Nematodes of the Antarctic fishes. Polish Polar Research 25, 135-152.

Rocka A. \& Zdzitowiecki K. 1998. Cestodes in fishes of the Weddell Sea. Acta Parasitologica 43, 64-70.

Rodjuk G.N. 1984. Novye predstaviteli roda Metechinorhynchus (Acanthocephala)-parazitov ryb Zapadnoj Antarktiki. (New representatives of the genus Metechinorhynchus [Acanthocephala] - parasites of fishes in the western Antarctic.) Zoologicheskii Zhurnal 63, 1893-1896.

Rokicki J., Rodyuk G., Zdzitowiecki K. \& Laskowcki Z. 2009. Larval ascaridoid nematodes (Anisakidae) in fish from the South Shetland Islands (Southern Ocean). Polish Polar Research 30, 49-58.

Shust K.V., Kuznetsova E.N., Kozlov A.N., Kokorin N.V. 8 Petrov A.F. 2005. Two species of toothfish in two basis long line fisheries regions-Patagonian toothfish in subarea 48.3 (South Atlantic) and Antarctic toothfish in subareas 88.1, 88.2 (South Pacific). Paper presented at the Working Group on Fish Stock Assessment of CCAMLR as document WGFSA-05/71. 10-21 October, Hobart, Australia.

Shust K.V. \& Petrov A.F. 2009. On captures of Patagonian toothfish Dissostichus eleginoides (Nototheniidae) in the highlatitude Antarctic regions. Journal of Ichthyology 49, 136-138. Shust K.V., Zarikhin I.P., Istomin I.G., Petrov A.F., Tatarnikov V.A. \& Demina N.S. 2009. Comparative characteristics of Patagonian (Dissostichus eleginoides) and Antarctic (D. mawsoni) toothfish inhabiting different sectors of the Southern Ocean. Paper presented at the Working Group on Fish Stock Assessment of CCAMLR as document WG-FSA-09/ 24. 12-23 October, Hobart, Australia.

Smith P.J., McKenzie A. \& Tubbs L. 2006. Preliminary analyses of an ectoparasite Eubranchiella antarctica as a marker for stock discrimination of Antarctic toothfish in the Ross Sea. Paper presented at the Working Group on Fish Stock Assessment of CCAMLR as document WG-FSA-06/28, 9-20 October, Hobart, Australia.

Sokolov S.G. \& Gordeev I.I. 2013. New data on trematodes (Plathelminthes, Trematoda) of fishes in the Ross Sea (Antarctic). Invertebrate Zoology 10, 255-267.

Sokolov S.G. \& Gordeev I.I. 2015. Novye dannye o trematodah antarkticeskih ryb. (New data on trematodes of Antarctic fishes.) Parazitologiya 49, 12-27.

Sokolov S., Gordeev I. \& Lebedeva D. 2016. Redescription of Proctophantastes gillissi (Overstreet et Pritchard, 1977) (Trematoda: Zoogonidae) with discussion on the systematic position of the genus Proctophantastes Odhner, 1911. Acta Parasitologica 61, 529-536.

Zdzitowiecki K. 1987. Digenetic trematodes from the alimentary tract of fishes off South Shetlands (Antarctic). Acta Parasitologica Polonica 32, 219-232.

Zdzitowiecki K. 1988. Occurrence of digenetic trematodes in fishes off South Shetlands (Antarctic). Acta Parasitologica Polonica 33, 155-167.

Zdzitowiecki K. 1990. Occurrence of acanthocephalans in fishes of the open sea off the South Shetlands and South Georgia (Antarctic). Acta Parasitologica Polonica 35, 131-141.

Zdzitowiecki K. 1991a. Occurrence of digeneans in open sea fishes off the South Shetland Islands and South Georgia, and a list of fish digeneans in the Antarctic. Polish Polar Research 12, 55-72.

Zdzitowiecki K. 1991b. Antarctic acanthocephalan. Synopsis of the Antarctic benthos. Vol. 3. Koenigstein: Koeltz Scientific Books.

Zdzitowiecki K. 1999. Digeneans of the families Opecoelidae and Lepocreadiidae, parasites of Lepidonotothen macrophthalma from the North Scotia Ridge, and remarks on the discrimination of Neolepidapedon magnatestis and N. trematomi. Acta Parasitologica 44, 233-240. 